\section{TÀI LIÊU THAM KHẢO}

1. Trân Quốc Toản (2015), Nghiên cứu nồng đô cystatin c huyết tương, nước tiểu ở bệnh nhân đái tháo đường týp 2 có tổn thương thận, Luận án Tiến sỹ Học viện 103.

2. Yoshiji Ogawaa, Takashi Gotob, Naoki Tamasawaa et al (2015), Serum cystatin C in diabetic patients, Diabetes reseach and clinical practice, Volume 79, Issue 2, Pages 357-361.

3. Alaaeldin M. Bashier, 1 Ayman Aly Seddik Fadlallah, 2,3 Nada Álhashemi,4 Puja Murli Thadani,1 Elamin Abdelgadir,1 and Fauzia Rashid1 (2015), Cystatin C and Its Role in Patients with Type 1 and Type 2 Diabetes Mellitus, Advances in Endocrinology, Volume 2015, 8 pages.

4. David M. Maahs, MD, PHD, 1,2 Nicole Prentice, BS, $1 \mathrm{Kim}$ McFann, PHD, 1 Janet K. Snell-Bergeon, PHD, 1Diana Jalal, MD,2 Franziska K. Bishop,
MS, 1 Brittany Aragon, BS, 1 and R. Paul Wadwa, $M D$ (2011), Age and Sex Influence Cystatin $C$ in Adolescents With and Without Type 1 Diabetes, Diabetes Care. 2011 Nov; 34(11): 2360-2362.

5. Dsa J, Shetty S, Bhandary RR, Rao AV. Association Between Serum Cystatin C and Creatinine in Chronic Kidney Disease Subjects Attending a Tertiary Health Care Centre. J Clin Diagn Res 2017 Apr; 11(4): BC09-BC12.

6. Rigalleau V. et al (2008), "Cystatin $C$ improves the diagnosis and stratification of chronic kidney disease, and the estimation of glomerular filtration rate diabetes", Diabetes and Metabolism. 34, tr. 482 - 489.

7. Yang YS, Peng CH và Lin CK et al (2007), "Use of Serum Cystatin C to Detect Early Decline of Glomerular Filtration Rate in Type 2 Diabetes", The journal of internal medicine. 46, tr. 801 - 806 .

\title{
KHẢO SÁT THỰC TRANG BÊNH NHÂN LIÊTT NỬA NGƯỜI DO ĐộT QUỴ NÃO TẠI BỆNH VIỆ̂̃N Y HỌC CỔ TRUYỀN CAO BẰNG
}

\author{
Vũ Thị Tâm¹, Lê Thị Tuyết Chinh², \\ Vũ Thị Hồng Anh', Vi Thị Thập Lan ${ }^{3}$
}

\section{TÓM TẮT}

Mục tiêu: Khảo sát thực trạng bệnh nhân liệt nửa người do đột quy não tại bệnh viện $Y$ hoc cổ truyền tại Cao Bằng. Đối tượng và phương pháp: Nghiên cứu mô tả trên 180 bênh nhân bi liêt nửa người do đột quy não đã điều trị tại bệnh viện Y học cổ truyền Cao Bằng thời gian từ ngày $1 / 1 / 2019$ đến ngày $1 / 6 / 2020$. Kết quả và kết luận: Tỉ lệ nam giới bị đột quỵ não chiếm đến $73,33 \%$, còn nữ giới chiếm $26,67 \%$. Tỷ lệ bị đột quy não dưới 60 tuổi là $67,22 \%$, trên 60 tuổi là $32,78 \%$. Tỷ lệ dân tộc kinh chiếm 8,89\%, dân tộc tày $47,22 \%$, các dân tộc khác chiếm 43,89\%. Bệnh nhân bị liệt bên trái chiếm $53,89 \%$, liệt bên phải chiếm $46,11 \%$. Đôt quy não do nhồi máu não chiếm tỉ lể lớn đến $71,67 \%$. Sau khi bị tai biến bệnh nhân được đưa đến viên chiếm $63,33 \%$. Tỉ lê bênh nhân bi đột quy não được sử dụng kết hợp thuốc đông y và tây y chiếm tỉ lê cao nhất $69,44 \%$.

Tư khóa: Đột quỵ não, phục hôi chức năng, vật lý trị liệu, nhồi máu não, vận động trị liệu

\section{SUMMARY \\ CURRENT STATUS OF PATIENTS WITH HEMIPARESIS DUE TO STROKE IN CAO BANG HOSPITAL OF TRADITIONAL MEDICINE}

\footnotetext{
${ }^{1}$ Trường đại hoc Y Dược Thái Nguyên

${ }^{2}$ Bệnh viện Y học cổ truyền Cao Bằng

${ }^{3}$ Bềnh viện Trung ương Thái Nguyên

Chịu trách nhiệm chính: Vũ Thị Tâm

Email: bstamphcn@gmail.com

Ngày nhận bài: 20.11.2020

Ngày phản biện khoa học: 25.12.2020

Ngày duyệt bài: 6.01.2021
}

Objective: To evaluate Current status of patients with hemiparesis due to stroke in Cao Bang hospital of traditional medicine. Subjects and methods: Observation study with 180 patients who was hemiparesis due to stroke in Cao Bang hospital of traditional medicine in the period from January, $1^{\text {st }}$ 2019 to June, $1^{\text {st }}$ 2020. Results and conclusions: The proportion of stroke male is $73,33 \%$ while the proportion of stroke female is $26,67 \%$. In terms of age group, the portion of under 60 -year-old group is $67,22 \%$ and the portion of above 60 -year-old group is $32,7 \%$. Regarding to ethnic group, the percentage of Kinh and Tay people is $8,89 \%$ and $47,22 \%$, respectively; while of the other ethnic groups is $43,89 \%$. The left-side hemiparesis group makes up $53,89 \%$ whilst the right-side hemiparesis group accounts for $53,89 \%$. Ischemic stroke makes up a huge proportion, at $71,67 \%$. There is $63,33 \%$ stroke patients are hospitalized. The percentage of patients who are treated with combination of alternative medicine and western medicine is the highest point, at $69,44 \%$.

Keywords: stroke, rehabilitation, ischemic stroke, physical therapy.

\section{I. ĐặT VẤN ĐỀ}

Đột quỵ não đã và đang là vấn đề thời sự cấp thiết của y học nói chung, của ngành phục hồi chức năng nói riêng đối với mọi quốc gia, dân tộc trên thế giới. Tai biến mạch máu não là bệnh lý do nhiêu nguyên nhân khác nhau gây ra, người bệnh có thể tử vong nhanh chóng hoặc nếu sống sốt sẽ để lại nhiều di chứng nặng nề. Theo Nguyễn Văn Đắng di chứng về vận động của đột quy. não là 92,62\%; di chứng nặng là 
$27,69 \%$; di chứng vừa và nhe là $68,42 \%$. Rối loạn chức năng vận động gây ảnh hưởng rất lớn và trực tiếp đến khả năng thực hiện các hoạt động sinh hoạt hàng ngày cũng như khả năng tái hổi nhâp vào đời sống cộng đồng. Theo thống kê năm 2014 tại Bệnh viện Y học cổ truyền Cao Bằng là bệnh viện hạng II, quy mô 150 giường bênh có số bênh nhân liệt nửa người đến điều trị chiếm 10,2\% tổng số bệnh nhân. Với mong muốn tìm ra những giải pháp can thiệp phù hợp nhằm để nâng cao hiệu quả điều trị cho bệnh nhân liêt tai Cao Bằng mà chúng tôi tiến hành đề tài nhẳm mục tiêu: Khảo sát thức trạng bênh nhân liệt nửa người do đột quy não tại bệnh viện Y học cổ truyền tại Cao Bằng.

II. ĐỐI TƯợNG VÀ PHƯƠNG PHÁP NGHIÊN CứU

\section{1. Đối tượng}

Tiêu chuẩn lựa chọn. Tất cả bệnh nhân bị liệt nửa người do đột quy. não đã điều trị tại bệnh viện $Y$ học cổ truyền Cao Bằng thời gian từ ngày $1 / 1 / 2019$ đến ngày $1 / 6 / 2020$.

Tiêu chuẩn loại trừ

- Những bệnh nhân liệt nửa người sau chấn

III. KẾT QUẢ NGHIÊN CỨU VÀ BÀN LUẬN

Bảng 3.1. Đặc điểm về giới của đối tượng nghiên cứu

\begin{tabular}{|c|c|c|c|c|c|c|c|c|}
\hline \multirow{2}{*}{\multicolumn{2}{|c|}{ Đặc điểm }} & \multicolumn{2}{|c|}{ Nhóm can thiệp } & \multicolumn{2}{|c|}{ Nhóm chứng } & \multicolumn{2}{|c|}{ Chung } & \multirow{2}{*}{$\mathbf{p}$} \\
\hline & & $n$ & $\%$ & $n$ & $\%$ & $n$ & $\%$ & \\
\hline \multirow{3}{*}{ Giới } & Nam & 64 & 71,11 & 68 & 75,56 & 132 & 73,33 & \multirow{3}{*}{$>0,05$} \\
\hline & Nữ & 26 & 28,89 & 22 & 24,44 & 48 & 26,67 & \\
\hline & Tổng & 90 & 100 & 90 & 100 & 180 & 100 & \\
\hline
\end{tabular}

Nhân xét: Tỉ lê bênh nhân là nam giới nhiều hơn nữa giới bi đột quy não, nam chiếm đến $73,33 \%$, còn nữ giới chiếm $26,67 \%$. Sự khác biệt có ý nghĩa thống kê.

Bảng 3.2. Đặc điểm về tuổi của đối tượng nghiên cứu

\begin{tabular}{|c|c|c|c|c|c|c|c|}
\hline \multirow{2}{*}{ Nhóm tuổi } & \multicolumn{2}{|c|}{ Nhóm can thiệp } & \multicolumn{2}{|c|}{ Nhóm chứng } & \multicolumn{2}{|c|}{ Chung } & \multirow[b]{2}{*}{$\mathbf{p}$} \\
\hline & $\mathrm{n}$ & $\%$ & $\mathbf{n}$ & $\%$ & $\mathbf{n}$ & $\%$ & \\
\hline$\leq 60$ & 65 & 53,72 & 56 & 46,28 & 121 & 67,22 & \multirow{6}{*}{$>0,05$} \\
\hline$>60$ & 25 & 42,37 & 34 & 57,63 & 59 & 32,78 & \\
\hline Tống & 90 & 100 & 90 & 100 & 180 & 100 & \\
\hline Trung bình & \multicolumn{2}{|c|}{$59,8 \pm 11$} & \multicolumn{2}{|c|}{$59,9 \pm 11,2$} & \multicolumn{2}{|c|}{$59,7 \pm 10$} & \\
\hline Thấp nhất & 33 & & 39 & & 33 & & \\
\hline Cao nhất & 78 & & 78 & & 78 & & \\
\hline
\end{tabular}

Nhận xét: Tỉ lệ bệnh nhân bị đột quỵ. nãodưới 60 tuối là $67,22 \%$, còn tỉ lệ tai biến trên 60 tuối là $32,78 \%$. Tuổi trung bình bị tai biến là 59,7 . Sự khác biệt có ý nghĩa thống kê.

Bảng 3.3. Đặc điểm về dân tộc của đồi tượng nghiên cứu

\begin{tabular}{|c|c|c|c|c|c|c|c|}
\hline \multirow{2}{*}{ Dân tộc } & \multicolumn{2}{|c|}{ Nhóm can thiệp } & \multicolumn{2}{|c|}{ Nhóm chứng } & \multicolumn{2}{|c|}{ Chung } & \multirow{2}{*}{ p } \\
\cline { 2 - 7 } & $\mathbf{n}$ & $\mathbf{\%}$ & $\mathbf{n}$ & $\mathbf{\%}$ & $\mathbf{n}$ & $\mathbf{\%}$ & \\
\hline Kinh & 7 & 7,78 & 9 & 10 & 16 & 8,89 & \\
\hline Tày & 43 & 47,78 & 42 & 46,67 & 85 & 47,22 & \multirow{2}{*}{$>0,05$} \\
\hline Khác & 40 & 44,44 & 39 & 43,33 & 79 & 43,89 & \\
\hline Tống & $\mathbf{9 0}$ & $\mathbf{1 0 0}$ & $\mathbf{9 0}$ & $\mathbf{1 0 0}$ & $\mathbf{1 8 0}$ & $\mathbf{1 0 0}$ & \\
\hline
\end{tabular}

Nhận xét: Tỉ lệ bệnh nhân là dân tộc kinh chiếm 8,89\%, dân tộc tày $47,22 \%$, các dân tộc khác chiếm 43,89\%. Sự khác biệt không có ý nghĩa thống kê. 
Bảng 3.4. Đặc điểm về bên liệt của đôii tượng nghiên cứu

\begin{tabular}{|c|c|c|c|c|c|c|c|c|}
\hline \multicolumn{2}{|c|}{ Đặc điểm } & \multicolumn{2}{c|}{ Nhóm can thiệp } & \multicolumn{2}{c|}{ Nhóm chứng } & \multicolumn{2}{c|}{ Chung } & \multirow{2}{*}{ p } \\
\cline { 2 - 9 } & Trái & 46 & 51,11 & 51 & 56,67 & 97 & 53,89 & \multirow{2}{*}{$>0,05$} \\
\cline { 1 - 9 } Bên liệt & Phải & 44 & 48,89 & 39 & 43,33 & 83 & 46,11 & \\
\cline { 2 - 9 } & Tống & $\mathbf{9 0}$ & $\mathbf{1 0 0}$ & $\mathbf{9 0}$ & $\mathbf{1 0 0}$ & $\mathbf{1 8 0}$ & $\mathbf{1 0 0}$ & \\
\hline
\end{tabular}

Nhân xét: Tỉ lệ bênh nhân bi đột quy não bị liệt bên trái chiếm $53,89 \%$, còn liêt bên phải chiếm $46,11 \%$, không có sự khác biệt giữa hai nhóm can thiệp và nhóm chứng về tỉ lệ bệnh nhân bị liệt bên trái hay bên phải.

Bảng 3.5. Đặc điểm về loại tổn thương của đôi tượng nghiên cứu

\begin{tabular}{|c|c|c|c|c|c|c|c|}
\hline \multirow[b]{2}{*}{ Loại tổn thương } & \multicolumn{2}{|c|}{ Nhóm can thiệp } & \multicolumn{2}{|c|}{ Nhóm chứng } & \multicolumn{2}{|c|}{ Chung } & \multirow[b]{2}{*}{$\mathbf{P}$} \\
\hline & $\mathbf{n}$ & $\%$ & $\mathbf{n}$ & $\%$ & $\mathbf{n}$ & $\%$ & \\
\hline Nhö̀ & 67 & 74,44 & 62 & 68,89 & 129 & 71,67 & \\
\hline Xuất huyết não & 23 & 25,56 & 28 & 31,11 & 51 & 28,33 & $>0,05$ \\
\hline Tống & 90 & 100 & 90 & 100 & 180 & 100 & \\
\hline
\end{tabular}

Nhận xét: Tỉ lệ bệnh nhân bị đột quy. não do nhồi máu não chiếm tỉ lệ lớn đến $71,67 \%$, còn nguyên nhân do xuất huyết não chỉ chiểm $28,33 \%$, không có sự khác biệt giữa hai nhóm can thiệp và nhóm chứng.

Bảng 3.6. Đặc điểm về thời gian bị bệnh của đôî tượng nghiên cứu

\begin{tabular}{|c|c|c|c|c|c|c|c|}
\hline \multirow{2}{*}{ Thời gian } & \multicolumn{2}{|c|}{ Nhóm can thiệp } & \multicolumn{2}{c|}{ Nhóm chứng } & \multicolumn{2}{c|}{ Chung } & \multirow{2}{*}{$\mathbf{p}$} \\
\cline { 2 - 8 } & $\mathbf{n}$ & $\mathbf{\%}$ & $\mathbf{n}$ & $\mathbf{\%}$ & $\mathbf{n}$ & $\mathbf{\%}$ & \multirow{2}{*}{ ( } \\
\hline Dưới 4 tuần & 28 & 35,56 & 22 & 24,44 & 54 & 30 & \\
\hline $4-12$ tuần & 29 & 37,78 & 23 & 25,56 & 57 & 31,67 & \multirow{2}{*}{$>0,05$} \\
\hline Trên 12 tuần & 33 & 36,67 & 45 & 50 & 69 & 38,33 & \\
\hline Tống & $\mathbf{9 0}$ & $\mathbf{1 0 0}$ & $\mathbf{9 0}$ & $\mathbf{1 0 0}$ & $\mathbf{1 8 0}$ & $\mathbf{1 0 0}$ & \\
\hline
\end{tabular}

Nhận xét: Tỉ lệ bệnh nhân bị đột quy nãocó thời gian bị bệnh trước khi vào điều trị đa dạng ở các mốc dưới 4 tuẩn là $30 \%$, từ 4 - 12 tuần là $31,67 \%$, trên 12 tuân là $38,33 \%$, không có sự khác biệt giữa hai nhóm can thiệp và nhóm chứng.

Bảng 3.7. Đặc điểm về tiền sử của đôi tượng nghiên cứu

\begin{tabular}{|c|c|c|c|c|c|c|c|}
\hline \multirow{2}{*}{ Tiên sử } & \multicolumn{2}{|c|}{ Nhóm can thiệp } & \multicolumn{2}{|c|}{ Nhóm chứng } & \multicolumn{2}{|c|}{ Chung } & \multirow[b]{2}{*}{$\mathbf{p}$} \\
\hline & $\mathbf{n}$ & $\%$ & $\mathbf{n}$ & $\%$ & $\mathbf{n}$ & $\%$ & \\
\hline Cao huyết áp & 59 & 65,56 & 61 & 67,78 & 120 & 66,67 & \\
\hline Mõ máu cao & 52 & 57,78 & 47 & 52,22 & 99 & 55 & \\
\hline Tiếu đường & 33 & 36,67 & 21 & 23,33 & 54 & 30 & \\
\hline Các bênh lý khác & 74 & 82,22 & 62 & 68,89 & 136 & 75,56 & \\
\hline Tê bì tay chân & 69 & 76,67 & 76 & 84,44 & 145 & 80,56 & \\
\hline Uống rượu & 34 & 37,78 & 41 & 45,56 & 75 & 41,67 & $>0,05$ \\
\hline Bệnh tim & 54 & 60 & 69 & 76,67 & 123 & 68,33 & \\
\hline Stress & 21 & 23,33 & 24 & 26,67 & 45 & 25 & \\
\hline Béo phì & 26 & 28,89 & 28 & 31,11 & 54 & 30 & \\
\hline Gắng sức & 33 & 36,67 & 41 & 45,56 & 74 & 41,11 & \\
\hline Đau nưa đầu & 74 & 82,22 & 62 & 68,89 & 136 & 75,56 & \\
\hline
\end{tabular}

Nhận xét: Tỉ lệ bệnh nhân bị đột quy não có kèm theo cao huyết áp chiếm $66,67 \%$, bị mõ máu cao chiếm $55 \%$, bị tiểu đường chiếm $30 \%$, bị tê bì tay chân chiếm $75,56 \%$, bị các bệnh lý khác chiếm $75,56 \%$, bị tim mạch chiếm $68,33 \%$, bị stress chiếm $25 \%$, bị béo phì chiếm $30 \%$, bị đau nửa đâuu chiếm $75,56 \%$, có hoạt động gắng sức chiếm $41,11 \%$, có uống rượu chiếm $41,67 \%$.

Bảng 3.8. Đặc điểm vể nơi được điều trị câp cứu ban đâu sau khi bị đột quy

\begin{tabular}{|c|c|c|c|c|c|c|c|}
\hline \multirow{2}{*}{$\begin{array}{c}\text { Nơi được điều trị } \\
\text { cấp cứu }\end{array}$} & \multicolumn{2}{|c|}{ Nhóm can thiệp } & \multicolumn{2}{|c|}{ Nhóm chứng } & \multicolumn{2}{|c|}{ Chung } & \multirow[b]{2}{*}{$\mathbf{p}$} \\
\hline & $\mathbf{n}$ & $\%$ & $\mathbf{n}$ & $\%$ & $\mathbf{n}$ & $\%$ & \\
\hline Ớ nhà & 3 & 3,33 & 7 & 7,78 & 10 & 5,56 & \\
\hline Trạm y tế & 24 & 26,67 & 32 & 35,56 & 56 & 31,11 & $>0,05$ \\
\hline Bệnh viện & 63 & 70 & 51 & 56,67 & 114 & 63,33 & \\
\hline Tống & 90 & 100 & 90 & 100 & 180 & 100 & \\
\hline
\end{tabular}


Nhận xét: Sau khi bị tai biến bệnh nhân được đưa đến viện chiếm 63,33\%, và có 31,11\% bệnh nhân được xứ trí tại trạm y tế, cũng có 5,56\% bệnh nhân được giữ lại điều trị tại nhà.

Bảng 3.9. Đặc điểm về thuốc được điều trị của đối tượng nghiên cứu

\begin{tabular}{|c|c|c|c|c|c|c|c|}
\hline \multirow{2}{*}{ Thuốc được điêu trị } & \multicolumn{2}{|c|}{ Nhóm can thiệp } & \multicolumn{2}{|c|}{ Nhóm chứng } & \multicolumn{2}{|c|}{ Chung } & \multirow[b]{2}{*}{$\mathbf{p}$} \\
\hline & $\mathbf{n}$ & $\%$ & $\mathbf{n}$ & $\%$ & $\mathbf{n}$ & $\%$ & \\
\hline Tây y & 13 & 14,44 & 10 & 11,11 & 23 & 12,78 & \\
\hline Đông y & 17 & 18,89 & 15 & 16,67 & 32 & 17,78 & $>0,05$ \\
\hline Cả hai loại thuốc trên & 60 & 66,67 & 65 & 72,22 & 125 & 69,44 & \\
\hline Tống & 90 & 100 & 90 & 100 & 180 & 100 & \\
\hline
\end{tabular}

Nhận xét: Tỉ lệ bệnh nhân bị đột quỵ não được sử dụng thuốc đông y là $17,78 \%$, còn thuốc tây y là $12,78 \%$. Song tỉ lệ bệnh nhân sử dụng kết hợp cả hai loại thuốc này chiếm tỉ lệ cao nhất $69,44 \%$.

Bảng 3.10. Đặc điểm về tiến triến của đôî tượng nghiên cứu

\begin{tabular}{|c|c|c|c|c|c|c|c|}
\hline \multirow[b]{2}{*}{ Tiến triển } & \multicolumn{2}{|c|}{ Nhóm can thiệp } & \multicolumn{2}{|c|}{ Nhóm chứng } & \multicolumn{2}{|c|}{ Chung } & \multirow[b]{2}{*}{ p } \\
\hline & $\mathbf{n}$ & $\%$ & $\mathbf{n}$ & $\%$ & $\mathbf{n}$ & $\%$ & \\
\hline Khá & 3 & 3,33 & 3 & 3,33 & 6 & 3,33 & \\
\hline Không đối & 25 & 27,78 & 18 & 20 & 43 & 23,89 & $>0,05$ \\
\hline Xấu hơn & 62 & 68,89 & 69 & 76,67 & 131 & 72,78 & \\
\hline Tống & 90 & 100 & 90 & 100 & 180 & 100 & \\
\hline
\end{tabular}

Nhận xét: Tỉ lệ bệnh nhân bị đột quỵ nãosau đó thấy tiến triển xấu hơn chiếm $72,78 \%$, còn thây các triểu chứng khồng đổi chiếm 23,89\%, khá hơn chiếm 3,33\%.

Bảng 3.11. Đặc điểm về nhà ở của đối tượng nghiên cứu

\begin{tabular}{|c|c|c|c|c|c|c|c|}
\hline \multirow{2}{*}{ Loại nhà } & \multicolumn{2}{|c|}{ Nhóm can thiệp } & \multicolumn{2}{|c|}{ Nhóm chứng } & \multicolumn{2}{c|}{ Chung } & \multirow{2}{*}{$\mathbf{p}$} \\
\cline { 2 - 7 } & $\mathbf{n}$ & $\mathbf{\%}$ & $\mathbf{n}$ & $\mathbf{\%}$ & $\mathbf{n}$ & $\mathbf{\%}$ & \multirow{2}{*}{$>0,05$} \\
\hline Nhà vách đất & 5 & 5,56 & 6 & 6,67 & 11 & 6,11 & \\
\hline Nhà gố & 13 & 14,44 & 10 & 11,11 & 23 & 12,78 & \multirow{2}{*}{$>0,32$} \\
\hline Nhà sàn & 12 & 13,33 & 11 & 12,22 & 23 & 12,78 & \\
\hline Nhà xây & 60 & 66,67 & 63 & 70 & 123 & 68,33 & \\
\hline Tống & $\mathbf{9 0}$ & $\mathbf{1 0 0}$ & $\mathbf{9 0}$ & $\mathbf{1 0 0}$ & $\mathbf{1 8 0}$ & $\mathbf{1 0 0}$ & \\
\hline
\end{tabular}

Nhân xét: Tỉ lệ bênh nhân bị đột quy não có nhà xây chiếm $68,33 \%$, nhà vách đất chiếm $6,11 \%$, nhà gố và nhà sàn chiếm tỉ lệ lần lượt là $12,78 \%, 12,78 \%$. Sự khác biệt không có ý nghĩa thống kê.

\section{BÀN LUÂ̂N}

4.1. Giới và tuổi. Trong 180 bệnh nhân nghiên cứu chúng tôi (bảng 3.1) có 132 nam (chiếm 73,33\%) và 48 nữ (chiếm 26,67\%) với tỷ lệ nam/ nữ là $2,75 / 1$. Bệnh gặp nhiều nhất ở đô tuổi $\leq 60$ (121 bệnh nhẩn, chiếm 67,22\%). Tuổi trung bình là 59,7 , tuổi thấp nhất là 33 , tuổi cao nhất là 78 tuổi.

Kết quả nghiên cứu của chúng tôi phù hợp với kết quả của một số nghiên cứu khác. Theo tiểu ban đột quy não của Hiệp hội Thần kinh $Y$ học các nước Đông Nam Á thì 58\% gặp ở nam giới. Nghiên cứu của Lê Văn Thính (2003) cho thây nhồi máu não gặp nhiều nhất từ tuổi 45 trở lên, chiếm $86,0 \%$, tỳ lệ nam/nữ là $2 / 1$. Theo Nguyễn Xuân Thản (2004) tại khoa Thần kinh Bệnh viện Quân Y 103 nhóm tuổi 45 - 74 cũng chiếm $67 \%$, tỷ lệ nam/nữ là 2,3/1 [6]. Nghiên cứu của Hà Hồng Linh (2005) tỷ lệ nam /nữ là 1,82/1, tuổi > 50 chiếm 62,9\% [3]. Nghiên cứu của Phạm Ngọc Anh (2005) tỷ lệ nhồi máu não ở tuổi 50 - 80 chiếm $90,5 \%$, tuổi trung bình là 63,0 , tỷ lệ nam/nữ là 1,63/1 [1]. Nghiên cứu của
Nguyễn Thị Kim Liên (2011) cho thây đột quy. não tuổi từ 45 trở lên chiếm $94 \%$, tuổi trung bình 59,2; tỷ lệ nam/nữ là 2,5/1[5].

Tuối được cho là yếu tố quan trọng nhất của đột quy não, tỷ lệ đột quy não tăng lên theo tuổi, ít xảy ra trước tuổi 40 và thường xảy ra ở độ tuổi từ 65 trở lên, nam giới bị đột quy. não nhiều hơn nữ giới. Một số tác giả giải thích là do nam giới hay sử dụng chất kích thích như rượu, thuốc lá... hơn nữ giới.

4.2. Bên liệt và tay thuận. Trong nghiên cứu của chúng tôi (bảng 3.4) 180 bệnh nhân: tỷ lệ liệt bên phải $46,11 \%$ thấp hơn bên trái $53,89 \%$. không có sự khác biệt giữa hai nhóm can thiệp và nhóm chứng về tî̉ lệ bệnh nhân bị liệt bên trái hay bên phải. Kết quả này cũng tương đồng với kết quả của các tác giả khác. Theo nghiên cứu Vũ Thị Kim Thanh (2012) tỷ lệ bệnh nhân liệt nửa người bên trái là $57 \%$, cao hởn tỷ lệ bệnh nhân liệt nửa người bên phải 43\%; tỷ lệ liệt bên trái/liệt bên phải là 1,3/1. Hoặc nghiên cứu của Broeks tỷ lệ liệt bên trái là $51,9 \%$ cao hơn bên phải là 48,1\% [7]. 
Kết quả của các tác giả đều thống nhất không có sự khác biệt có ý nghĩa thống kê $(p>0,05)$ đối với bên liệt của bệnh nhân đột quỵ não. Như vậy số liệu của chúng tôi cũng phù hợp.

4.3. Thời gian bị bệnh của đối tượng nghiên cứu. Kết quả nghiên cứu của chúng tôi cho thây tỉ lệ bệnh nhân bị đột quy não có thời gian bi bênh trước khi vào điều trị đa dang ở các mốc dưới 4 tuần là $30 \%$, từ $4-12$ tuần là $31,67 \%$, trên 12 tuần là 38,33\%, không có sự khác biệt giữa hai nhóm can thiệp và nhóm chứng. Kết quả này cũng tương đồng với kết quả của các tác giả khác.

Thời gian đến viện càng sớm sẽ khiến cho việc tập luyên phục hồi chức năng mang lại hiệu quả cao hơn đồng thời ít xảy ra các thương tật thứ cấp kèm theo do bất động lâu ngày ở tư thế co cứng do tai biến. Các nghiên cứu về phục hồi chức năng đã cho kết luận khả năng phục hồi tốt nhất của bệnh nhân liệt nửa người do đột quy. não xảy ra từ 3 - 6 tháng đầu tiên sau đột quy. Tổ chức Y tế thế giới (1971) đã có khuyến cáo là ngay từ những ngày đầu tiên sau đột quy., kể cả khi bênh nhân vần còn hôn mê thì viẹc phòng chống co cứng, biến dạng co rút và các thương tật thứ cấp khác sau này cũng phải được coi trọng như là phòng chống loét và các biến chứng khác trong giai đoạn cấp. Nhiều tác giả qua nghiên cứu về bệnh nhân liệt nửa người cho thấy bệnh nhân nếu được bắt đẩu tập luyện phục hồi chức năng sớm thì kết quả phục hồi sẽ tốt hơn nhiều so với bắt đầu phục hồi muộn. Tuy nhiên tác giả chưa thống nhất thời gian bao nhiêu là sớm. Nhiều tác giả cho rằng bệnh nhân được bắt đầu tập luyện từ 1 đến 6 tuần sau đột quy là giai đoạn sớm của phục hồi chức năng.

4.4. Tiền sử bị bệnh của đối tượng nghiên cứu. Kết quả nghiên cứu của chúng tồ cho thấy tỉ lệ bệnh nhân bị đột quỵ não có kèm theo cao huyết áp chiếm $66,67 \%$, bị mõ máu cao chiếm $55 \%$, bị tiểu đường chiếm $30 \%$, bị tê bì tay chân chiếm $75,56 \%$, bị các bệnh lý khác chiếm $75,56 \%$, bị tim mạch chiếm $68,33 \%$, bi stress chiếm $25 \%$, bị béo phì chiếm $30 \%$, bị đau nửa đầu chiếm $75,56 \%$, có hoạt động gắng sức chiếm $41,11 \%$, có uống rượu chiếm $41,67 \%$. Kết quả này cũng tương đồng với kết quả của các tác giả khác. Việc bệnh nhân có nhiều bệnh kèm theo sẽ là yếu tổ ảnh hưởng đến kết quả tập luyện phục hồi chức năng cho bệnh nhân tai biến, ảnh hưởng đến tiên lượng phục hồi.

\subsection{Nơi được điều trị cấp cứu ban đâu và thuốc sử dụng của đối tượng nghiên} cứu. Kết quả nghiên cứu của chúng tôi cho thấy tỉ lệ bệnh nhân bị đột quy. não được xử trí trước khi đến bệnh viện $Y$ học cổ truyền cho thấy phần lớn sau khi bị tai biến thường bệnh nhân được đưa đến viện chiếm $63,33 \%$, và có $31,11 \%$ bệnh nhân được xứ trí tại trạm y tế, cũng có $5,56 \%$ bệnh nhẩn được giữ lại điều trị tại nhà, theo đó 10 bệnh nhân điều trị tại nhà để đắp thuốc và điều trị bằng châm cứu, đó cũng là các bệnh nhân có mức độ liệt tương đối nặng, gia đình có hoàn cảnh kinh tế khó khăn. Việc bệnh nhân được sử trí tại bênh viện và các trung tâm y tế cũng ảnh hưởng đến kết quả phục hồi chức năng, những điều trị không đúng sẽ làm cho các thương tật thứ cấ trở nên nặng nề hơn. Tỉ lệ bệnh nhân bị đột quy não được sử dụng thuốc đổng y là $17,78 \%$, còn thuốc tây y là $12,78 \%$. Song tỉ lệ bệnh nhân sử dụng kết hợp cả hai loại thuốc này chiếm tỉ lệ cao nhất 69,44\%.

4.6. Đặc điểm về tổn thương não. Trong 180 bệnh nhân nghiên cứu của chúng tôi, nhồi máu não chiếm tỉ lệ lớn đến $71,67 \%$, còn nguyên nhân gây tai biến do xuất huyết não chỉ chiểm 28,33\%, không có sự khác biệt giữa hai nhóm can thiệp và nhóm chứng. Kết quả này cũng tương đồng với kêt quả của các tác giả khác.

Theo Nguyển Văn Đăng tỷ xuất giữa ngồi máu não/ chảy máu não bằng 2 [2]. Trần Văn Chương, nhận thấy nhồi máu não chiếm $77,33 \%$, còn chảy máu não là $22,67 \%$. Ma Thị Kim Liên cho biết nhồi máu não chiếm 52,13\% và $47,8 \%$ là chảy máu não [4].

\section{KẾT LUẬN}

Tỉ lệ nam giới bị đột quy não chiếm đến $73,33 \%$, còn nữ giới chiếm $26,67 \%$. Tỉ lệ bệnh nhân bị đột quy não dưới 60 tuổi là $67,22 \%$, trên 60 tuổi là $32,78 \%$. Tỉ lệ bệnh nhân dân tộc kinh chiếm $8,89 \%$, dân tộc tày $47,22 \%$, các dân tộc khác chiếm $43,89 \%$. Tỉ lệ bị liệt bên trái chiếm $53,89 \%$, còn liệt bên phải chiểm $46,11 \%$. Tỉ lệ bệnh nhân bị đột quy não do nhồi máu não chiếm tỉ lệ lớn đến $71,67 \%$. Sau khi bị tai biến bệnh nhân được đưa đến viện chiếm 63,33\%. Tỉ lệ bệnh nhân bị đột quy não được sử dụng kết hợp thuốc đông y và tây y chiếm tỉ lệ cao nhất $69,44 \%$.

\section{TÀl LIẸU THAM KHẢO}

1. Phạm Ngọc Anh (2005). Bước đâu đánh giá hiệu quả hoạt động tri liệu trong PHCN chi trên ở bệnh nhân liệt nửa người do nhồi máu não. Luận văn chuyên khoa cấp II, Trường Đại học Y Hà Nội, tr 57

2. Nguyễn Văn Đăng (1996). Tình hình tai biến mạch máu não tại khoa Thân kinh Bệnh viện Bạch Mai 1991 - 1993. Kỷ yếu công trình khoa học thân kinh, Nhà xuất bản Y học, tr. 101 - 109. 
3. Phan Quan Chí Hiếu, Hà Thị Hồng Linh (2005). Hiêu quả phuc hồi vận động của phương pháp thể châm cải tiến trên bệnh nhân tai biến mach máu não. Luận án tốt nghiệp cao học Y học cố truyền, Đai hoc Ỳ dước TP. HCM̀, tr 79.

4. Ma Thị Kim Liền (2006). Nghiên cứu một số yếu tố liên quan đến mức độ đối lập trong sinh hoạt và nhu câuu phục hồi chức năng của người bệnh sau tai biến mạch máu não tại cộng đồng. Luận văn thạc sỹ, tr.25 - 37.
5. Nguyễn Thị Kim Liên (2011). Nghiên cứu phục hồi chức năng bàn tay trên bênh nhân liêt nửa người do tai biến mạch máu não. Luận văn tiến sỹ Y họ, Trường Đại học Y Hà Nội, tr. 90 - 95.

6. Nguyễn Xuân Thản (2004). Bệnh mạch máu não và tủy sống. Nhà xuất bản Y học, tr 265 - 266.

7. Vũ Thi Kim Thanh (2012). Đánh giá hiêu quả phục hồi chức năng vận động chi trên ở bệnh nhân tai biến nhồi máu vùng trền lều. Luận văn thạc sỹ y học, Đại học Y Hà Nội, tr 55.

\section{DÂY RỐN QUẤN CỔ LÚC SINH VÀ KẾT CỤC TRÊN THAI NHI TẠI BỆNH VIỆN SẢN NHI AN GIANG}

\section{TÓM TẮT}

Đặt vấn đê: Dây rốn quấn cổ (DRQC) là một hiện tượng thường găp vào những tháng cuối của thai kỳ và có thể gây bất lợi cho thai nhi. Mục tiêu của nghiên cứu này nhằm xác định mối liên quan giữa DRQC một vòng với kết cục bất lợi trên thai nhi. Đối tượng và phương pháp: Một nghiên cứu bệnh-chứng với tỉ lệ 1:2 thực hiện tại Phòng sinh bệnh viện Sản Nhi An Giang từ 3/2019-12/2019, nhóm bênh gồm 90 sản phụ có DRQC một vòng và nhóm chứng gôm 180 sản phụ không có DRQC. Kết quả:. DRQC một vòng khổng làm tăng nguy cơ ối nhuộm phân su, biểu đồ tim thai bất thường, sử dụng oxytocin để tăng co trong quá trình chuyển dạ, cũng như không làm tăng nguy cơ sinh mổ và trẻ ngạt sau sinh. Kết luận: Không có mối liên quan giữa DRQC một vòng với các yếu tố nguy cơ trong chuyển da và kết cục trên thai nhi.

Tư khóa: Dây rốn quấn cổ, kết cục thai nhi

\section{SUMMARY}

NUCHAL CORD AT DELIVERY AND

PERINATAL OUTCOMES AT THE WOMEN

\section{AND CHILDREN HOSPITAL OF AN GIANG}

Background: Nuchal cord is a common phenomenon in the late months of pregnancy and can be detrimental to the fetus. The objective of this study was to determine the association of nuchal cord with the unfavorable outcomes for newborns. Subjects and methods: A 1: 2 case-control study conducted at the delivery rooms at the Women and Children hospital of An Giang from 3/2019 to 12/2019, a group of 90 women with nuchal cord and a control group of 180 women without nuchal cord. Results: Nuchal cord did not increase the risk of meconium-stained amniotic fluid, abnormal cardiotocography, increased using oxytocin during labor, and did not increase

${ }^{1}$ Dại học Y Dược Cần Tho

${ }^{2}$ Bệnh viện Sản Nhi An Giang

Chịu trách nhiệm chính: Nguyễn Ngọc Rạng

Email: nguyenngocrang@gmail.com

Ngày nhận bài: 19.11.2020

Ngày phản biện khoa học: 23.12.2020

Ngày duyệt bài: 6.01.2021

\section{Nguyễn Ngọc Rạng ${ }^{1}$, Trương Kim Thuyên ${ }^{2}$}

cesarean section and postpartum asphyxia. Conclusions: There is no association between nuchal cord and risk factors for unfavoable perinatal outcomes.

Keywords: Nucal cord, perinatal outcomes

\section{I. ĐĂT VẤN ĐỀ}

Dây rốn quấn cổ (DRQC) là hiện tượng dây rốn quấn quanh cổ thai nhi một vòng hoặc nhiều vòng, thường gặp trong những tháng cuối của thai kỳ. DRQC là một trong những biến chứng thường gặp trong thai kỳ nó gây một số bất lợi cho thai nhi: nhịp tim thai giảm bất định, ối nhuộm phân su, tăng tỉ lệ mổ sanh, và chỉ số Apgar thấp, thai chết lưu [1]. Một phân tích tổng hợp gồm 145 nghiên cứu, DRQC một vòng chiếm $22 \%$ tổng số sinh và khoảng $4 \%$ trường hợp đối với trường DRQC từ hai vòng trở lên và tăng dân trong suốt thai kỳ.[2] Sự hiện diện của số vòng DRQC phụ thuộc vào lượng nước ối và sự cử động của thai nhi. DRQC thường xuất hiện khi chiều dài dây rốn chiếm hơn 4/5 chiều dài thai nhi, có thể làm thay đổi tân số tim thai. Áp lực tử cung tăng trong lúc chuyển dạ gây tăng áp lực liên tục trên dây rốn có thể có hại cho thai nhi [1],[3]. Tuy nhiên, một số tác giả không tìm thấy mối liên quan giữa DRQC với bất Iợi cho thai kỳ [4] [8]. Thực tế DRQC luôn là nỗi lo của đa số các thai phụ nhất là trong giai đoạn chuyển dạ và thường yêu câu được sinh mổ thay vì sinh ngã âm đạo. Điều này luôn tạo áp lực cho các bác sĩ sản khoa và nữ hô sinh.

Khảo sát nhanh trong một tháng, tỉ lệ DRQC của các thai phụ đến sinh tại bệnh viện Sản Nhi An Giang là 13\%, trong đó có 4,7\% DRQC nhiều hơn một vòng. Đa số các trường hợp $\mathrm{DRQC}$ từ hai vòng trở lên được chẩn đoán qua siêu âm thường có chỉ định sinh mổ trừ các trường hợp không được biết trước. Trường hợp DRQC một vòng nếu không kèm theo một yếu tố bất thường nào khác sẽ được theo dõi sinh ngã âm 